\title{
What is Left in the "Too Hard Basket"? Developments and Challenges for the Rights of Children in Conflict with the Law
}

\author{
Nessa Lynch \\ Associate Professor, Faculty of Law, Te Herenga Waka - Victoria University \\ of Wellington, Wellington, New Zealand \\ nessa.lynch@vuw.ac.nz
}

\section{Ton Liefaard}

Vice-Dean and UNICEF Chair in Children's Rights at Leiden Law School, Leiden University, Leiden, the Netherlands

t.liefaard@law.leidenuniv.nl

\begin{abstract}
The 30 years since the enactment of the United Nations Convention on the Rights of the Child has seen extensive developments in the theory and practice of children's rights. Children's rights are now an established academic discipline with the study of children in conflict with the law being a fundamental area of analysis. This paper takes the approach of highlighting three areas of development of children's rights scholarship in relation to the criminal justice system: children's rights, developmental science and notable themes emerging from cross-national scholarship, including age limits, diversion, effective participation and deprivation of liberty. In addition, it analyses three gaps or challenges which are "left in the too-hard basket" for the coming decades.
\end{abstract}

\section{Keywords}

children's rights - children in conflict with the law - youth justice - child justice juvenile justice 
The 30 years since the enactment of the United Nations Convention on the Rights of the Child ("the Convention" or "CRC") has seen extensive developments in the theory and practice of children's rights. Children's rights are now an established academic discipline, albeit 'complex, dynamic, and relatively young' (Kilkelly and Liefaard, 2019a) with the study of children in conflict with the law being a fundamental area of analysis. For example, a survey of articles published since the inception of this journal yields a wide variety of criminal justice-related topics, ranging from participation of children in court proceedings (Rap, 2016) to capital punishment (Linde, 2011; James and Cecil, 20032004; James, 2001). Jurisdiction-specific analyses are prevalent, with Canada (e.g. Trepanier and Tulkens, 1993; Pinero, 2009; Bendo and Mitchell, 2017), and Australia (e.g. O'Brien and Fitzgibbon, 2018; Nunez and Copeland, 2017; De Jonge, 1995) being the most prevalent.

It would be impossible within the parameters of this paper completely to cover the extensive developments in scholarship, or indeed the case-law and human rights jurisprudence across these three decades. This paper takes the approach of highlighting three areas of development of children's rights scholarship in relation to the criminal justice system, and three gaps or challenges which are "left in the too-hard basket" for the coming decades. These are not exhaustive and undoubtedly reflect our personal areas of scholarship and geographical locations. We also recognise the dearth of global coverage in the scholarly literature (though note Banks, 2007; 2011; Ame, 2011 in this journal). and the primacy of the English language medium.

Finally, a note on terminology - we use the term children here in its Convention sense, referring to those aged less than 18 , while noting that many jurisdictions have lower ages of penal majority. We also note that one of the issues that we have identified is that some children accused of serious crimes are excluded from the youth justice system. Therefore, we have chosen to use the term "criminal justice system", to recognise that not all children in conflict with the law benefit from a specialised youth justice system. We note also that the Committee on the Rights of the Child has decided to advocate for the use of the term "child justice" - instead of "juvenile justice" or "youth justice" (GC No. 24., 2019).

This section chooses three key areas of developments in scholarship relating to the rights of children in conflict with the law. These are the analysis of the 
human rights framework for such children across three decades, the increasing emphasis on applying scientific understanding to law, practice and policy; and some notable themes of aspects of youth justice systems which emerge from cross-national scholarship.

\subsection{Children's Rights for Children in Conflict with the Law}

The rights of children in conflict with the law are firmly embedded in international human and children's rights. Children's rights form part of international and regional human rights law and reflect fundamental human rights notions, such as the right to a fair trial, while adding child-specific components (Hollingsworth, 2013). Core children's rights provisions, in particular articles 40 and 37 of the Convention, revolve around the right of 'every child alleged as, accused of, or recognized as having infringed the penal law' (art. 40 (1), CRC) to be treated fairly, with respect for fair trial rights including the presumption of innocence, the right to legal or other appropriate assistance and the right to a trial without delay (see art. 40 (2), CRC), and in a manner that takes into account the child's age and her or his best interests (Liefaard, 2015). Children's rights for children in conflict with the law places states under the obligation to promote the child's well-being, development and social reintegration, while reinforcing her or his respect for human rights and fundamental freedoms of others (see also art. 29 (1), CRC). To this end, states are required and have been stimulated to develop specific laws and policies for children in conflict with the law and invest in the specialisation of professionals (General Comment No. 10, para. goff.; see also the new General Comment No. 24, para. 105ff.), provide for measures without resorting to judicial proceedings - i.e. diversion and set an age below which children cannot be held criminally responsible (i.e. the minimum age of criminal responsibility, MACR) (art. 40 (3), CRC). Although, the Convention itself does not provide for an age and the 1985 UN Standard Minimum Rules for the Administration of Juvenile Justice (the Beijing Rules) merely provide that the age 'shall not be fixed at a too low an age level' (rule 4.1), the UN Committee of the Rights of Child, for a long time, has advocated for a MACR of 12 years of age, as the 'international acceptable minimum' (General Comment No. 10, para. 32). In its recent 24th General Comment on children's rights in the child justice system, which replaces General Comment No. 10, the Committee calls for a MACR of at least 14 years of age (para. 22). The Committee also 'commends States parties that have a higher minimum age, for instance of 15 or 16 years of age, and urges States parties not to reduce the minimum age of criminal responsibility under any circumstances' (para. 22).

The Committee furthermore underscores that all children, who were under 18 at the time of committing the offence, should be granted the right to be protected under the children's rights framework, and therefore denounces 
the practice of transferring or waiver children to the adult court or to the adult penal system (General Comment No. 24, para. 30). It does so on the basis of the principle of non-discrimination, which has broader implications for the criminal justice system and relates to issues such as discrimination and disparities, status offences and stigmatisation (General Comment No. 24, para. 112; see also General Comment No. 10, para. 6-9). As far as sentencing and the use of deprivation of liberty is concerned, children's rights standards advocate for lower sentences and, more importantly, child-sensitive dispositions (see General Comment No. 24 and art. 37 (a) and (c) and article 40 (4), CRC) and call for the use of arrest, detention and imprisonment as a measure of last resort and for the shortest appropriate period of time (art. 37 (b), CRC).

Scholarship has identified that human and children's rights have stimulated law reform (see e.g. Zimring, Langer and Tanenhaus, 2015; see also SlothNielsen, 2001) and jurisprudence to secure treatment of children in conflict with the law in conformity with human rights (Skelton, 2018). In addition, it has been identified that the framework has generated further standard-setting in specific areas of criminal justice. The Inter-American Court of Human Rights, for example, has delivered ground-breaking jurisprudence in relation to street children and police violence, and the protection of children under arrest and in detention (Feria Tinta, 2015 with reference to the Villangrán Morales v. Guatemala case, among others). The Council of Europe, particularly through its European Court of Human Rights and its case law on children's right to effective participation (Kilkelly, 2001; Rap, 2013; $T \& V v . U K$ cases), the right to legal assistance (Liefaard and Van den Brink, 2014; Salduz case and Panovits case) and the use of detention as a last resort and for the shortest period of time (Van den Brink, 2018), and the Committee of Ministers, have developed specific instruments around child-friendly justice (Liefaard and Kilkelly, 2018; cf. Sloth-Nielsen, 2015), the rights of children subjected to detention and community sentences and 'new ways of dealing with juvenile delinquency'; the latter reflecting scientific insights regarding development of adolescents, including brain development (see below). In 2016, the European Union adopted a special directive on procedural safeguards for children who are suspects or accused persons in criminal proceedings, which is grounded in children's rights and European human rights and is legally binding for EU member states (see Rap and Zlotnik, 2018).

In sum, children's rights for children in conflict with the law have not only provided more clarity and guidance on the role and responsibilities of states for the protection of the rights and interests of children dealt with within the criminal justice system, it has also (further) stimulated law reform at the domestic level. Regional standard-setting and the activities of civil society 
organisations as well as UN special mandate holders, in particular the UN Special Representative on Violence Against Children, around awareness raising and training of law makers, judges, prosecutors, law enforcement, social workers and other professionals, have certainly contributed to this achievement. Unfortunately, this cannot be said for all parts of the world, primarily because of the absence of a regional human rights infrastructure. In addition, it should be noted that regressive trends towards juvenile delinquency, and crime more generally, in some countries show that the principles and rights laid down in the human rights framework are not without controversy (O'Brien and Fitzgibbon, 2018; Liefaard, forthcoming; Hollingsworth, 2016).

\subsection{Developmental Science, Children and Criminal Justice}

A different, though related, lens of scholarship is that of developmental psychology (the terms "brain science" and "neuroscience" are also used). The extensive literature has been used successfully in advocacy and strategic litigation to temper the effect of punitive laws and policies, particularly in the United States (Steinberg and Scott, 2003). While the human rights lens and the scientific lens are different conceptions of children's rights and interests, they arguably lead to a similar result - a recognition that it is right and justified to treat children in an age appropriate manner and to emphasise outcomes which recognise children's lesser capacities for self-control and regulation, but their greater capacity for change and re-integration.

This body of scientific literature has been employed in two main contexts for children in conflict with the law. The first is evidence about the stages of brain development in children. Research emphasises children's lesser stage of cognitive development, susceptibility to peer influence and risk-taking behaviour, and lesser capabilities for self-control and self-regulation (Grisso and Schwartz, 200o). Children's brains are still developing until late adolescence or early adulthood. Their capacity for change and rehabilitation is considerable. International research projects have demonstrated that these findings are cross-cultural (Steinberg, 2009; Scott and Steinberg, 2008). In criminal cases, this evidence can be employed at both the liability assessment and the sentencing stage. Recent United States decisions such as Miller v. Alabama (finding mandatory life without parole to be unconstitutional) have relied heavily on scientific evidence of teenagers' brain development to support an argument of lesser culpability (Monahan et al., 2015; Cohen and Casey, 2014). Further, children's capacity for change and greater opportunities for re-integration justify finite and shorter sentences. Another use of brain development evidence is in the policy and law reform sphere. Here, it underpins arguments for higher minimum ages of criminal responsibility, age-appropriate sentencing, also for 
young adults, and the retention of the presumption of doli incapax (Steinberg, 2009).

In the second context (which draws together the scientific and human rights lenses), there is increasing knowledge of the prevalence of cognitive difficulties amongst the population of children in conflict with the law, particularly those children who commit serious offences. Cognitive difficulties may arise from traumatic brain injury, abuse and neglect, neuro-disabilities such as autism, ADHD, foetal alcohol spectrum disorders, intellectual disability and mental illness. Children with these difficulties are highly over-represented in the criminal justice system, particularly in the custodial population (Hughes, 2012; Lynch, 2016). While all children may struggle with comprehension of complex legal processes simply as a result of their stage of development, children with cognitive difficulties face further barriers in the vindication of their rights to effective and meaningful participation in particular, and also recognition of their conditions as a mitigating factor in sentencing. Diagnosis is a key issue, particularly as some of these conditions can manifest first as defiance or a child being non-compliant with requirements such as curfew or bail conditions (Hand et al., 2016). Court processes can be improved through the use of communication assistance/intermediaries who use their expertise in speech and language to explain and interpret proceedings to children (Hoyano, 2015).

Scientific understanding provides standalone evidence for protective measures and mitigation for children in conflict with the law. It has been said that with increasing knowledge both of developmental psychology and the prevalence of cognitive difficulties in the youth justice population, we may look back at aspects of our contemporary laws, policy and practice for children in conflict in the law as being akin to asking a person in a wheelchair to run up the stairs (Becroft, quoted in Lynch, 2016). The literature has been used to powerful effect in the United States, where the political and social context means that human rights are not a powerful argument for mitigation and protective measures for children (Rutkow and Lozman, 2006). It is possible that there are some fishhooks in basing protective measures purely on scientific evidence, rather than the universal application of human rights (Walsh, 2010). What if an assessment shows that a young child is capable of understanding and fully culpable for their actions? That should not override the requirements in human rights standards for special measures for children. Traumatic brain injuries and other neuro-disabilities may also be used as a double-edged sword to class particular children as particularly risky and justify more restrictive measures (Freckleton, 2016). Again, the universality of the requirements for special measures must prevail (UN Committee on the Rights of the Child, 2019, para. 28). 
Though separate lenses, scientific findings are increasingly used in human rights analysis to justify protective measures for children. For instance, the recent updated General Comment uses brain development evidence to justify the recommendation of a higher minimum age of criminal responsibility:

documented evidence in the fields of child development and neuroscience indicates that maturity and the capacity for abstract reasoning is still evolving in children aged 12 to 13 years due to the fact that their frontal cortex is still developing... States parties are encouraged to take note of recent scientific findings, and to increase their minimum age accordingly, to at least 14 years of age (UN Committee on the Rights of the Child, 2019, para. 22).

\subsection{Children's Rights in Youth Justice Systems - Cross-National Trends in Theory and Practice}

2.3.1 Criminal Responsibility and Age Parameters

The minimum age of criminal responsibility, the age of penal majority and various age parameters are the subject of much scholarship. As discussed above, both the human rights lens and the scientific lens have been used to critique minimum ages of criminal responsibility (Morgan and Farmer, 2011; McDiarmid, 2013). Comparative analyses (e.g. Cipriani, 2016) are prevalent in the literature, though may fail to capture the particularities of individual systems. As discussed above, recently the Committee on the Rights of the Child has reached a firm consensus in relation to the age of 14 years (General Comment, 2019, para. 22), regarding scientific findings as weighty:

States parties are encouraged to take note of recent scientific findings, and to increase their minimum age accordingly, to at least 14 years of age. Moreover, the developmental and neuroscience evidence indicates that adolescent brains continue to mature even beyond the teenage years, affecting certain kinds of decision-making. Therefore, the Committee commends States parties that have a higher minimum age, for instance 15 or 16 years of age, and urges States parties not to reduce the minimum age of criminal responsibility under any circumstances.

Many states have forms of parental responsibility enshrined in law (Eekelaar, 1991). Hollingsworth (2007) has explored the overlapping nature of the rights of the child and the rights of the parents under the English scheme for parental responsibility for the crimes of their children. 
2.3.2 Diversion, Alternatives and Restorative Justice

Diversion from prosecution is longstanding in national systems for children in conflict with the law. Diversion may mean simply that nothing further happens, or that a child is referred by the police or enforcement officer towards a programme - such as a referral to social services, educational or drug and alcohol services. Children may be required to make amends for the harm, such as paying small amounts of compensation or reparation, or doing community work.

A principled, consensual and well-delivered diversion process can have considerable advantages for children's rights and interests, delivering a resolution in line with a child's sense of time, and providing a re-integrative outcome that addresses the child's needs. The prevalent use of diversion may act to mitigate somewhat the continued low minimum ages of criminal responsibility in many jurisdictions, by resolving the matter at the lowest level possible. Importantly, diversion should ensure that a child does not have a criminal record which causes stigma and hinders future opportunities such as work and travel. There is rightly caution that children's due process rights are protected, that such processes do not leave the child with a permanent record, and that children participate fully in the agreement to enter the process (Sands, 2016).

Concurrent with the drafting and signing of the Convention in the late 1980s, was the increasing popularity of restorative justice $(\mathrm{RJ})$ processes. Restorative justice is broadly defined as a communitarian and participatory form of justice, which seeks to return control of a crime and its aftermath to the people involved, namely the alleged offender and the victim of the offence (Crawford and Newburn, 2013). Restoration and reconciliation are goals rather than retribution and deterrence, and decisions may be binding on participants or recommendatory to judicial officers (Morris and Maxwell, 2001). Models of restorative practice are widely used for children in conflict with the law. Prevalent especially is the family group conferencing model, which was pioneered in New Zealand (Maxwell and Morris, 2006). Scholarship has examined how RJ interacts with children's rights. It can promote children's rights (Moore and Mitchell, 2011). Moore (2008: 9) argues that -

the language of CRC Article 40 is ... largely indicative of the principles of restorative practice. Notions of respect, dignity, construction and reintegration evoke restorative collaboration, community stakeholder involvement, and dialogue - especially in combination with CRC articles 2, 3, 6 and 12. 
However, it is difficult to reconcile the best interests of the child standard with the victim-focused approach of restorative justice, and there are doubts as to whether some children have sufficient maturity for expressions of remorse (Lynch, 2010).

In a response to indigenous peoples' desire for self-determination and attempts to address the stark over-representation of indigenous children in the justice system, some jurisdictions have seen the establishment of specific courts for indigenous children and their families (Borowski, 2011). Australian jurisdictions' courts are statutorily based, while the New Zealand model is grassroots (or 'flaxroots'), with local Maori communities partnering with judges to provide a culturally appropriate venue, process and outcome (Taumaunu, 2014). Such initiatives give effect to indigenous peoples' rights to selfdetermination and practice of culture and have been endorsed by the recent updated General Comment.

\subsubsection{Children's Rights in Court Proceedings}

As discussed, there is a cross-national trend towards some form of diversion for most children coming to notice for minor or moderate offending. This has the result that although the numbers being dealt with through charges in a formal court setting or eventual custodial disposition are low, these cases are the most complex in terms of both the offence and the child. When the principles of diversion and "deprivation of liberty as a last resort" is employed thoroughly, children who eventuate in court or custody may have exhausted the available options and community placements over many years. Communication disorders, cognitive difficulties and mental health issues are prevalent amongst this population. Previous care history is often prevalent to the extent that the pipeline from care to custody seems ubiquitous and inevitable (Stanley, 2017). Over-represented populations also include ethnic or social minorities (Kempf-Leonard, 2007, Webster, 2018), children with immigrant status (Liddell et al., 2017) or refugee status and indigenous peoples (Cuneen, 2006). These smaller numbers also have the potential to transform practice in courts and custody from volume processing to evidence-based intervention. Therapeutic jurisprudence and problem-solving courts such as specialist drug courts and judicial monitoring are promising initiatives for promoting children's reintegration into society (Richards et al., 2017).

Scholarship on children's rights in court proceedings has focussed on the difficulties of children participating in court proceedings. Courtroom design, attitude of professionals, timetables and language all inhibit the child's rights to effective and meaningful participation (Kilkelly, 2008; Rap, 2015; Forde, 2018; 
Daly and Rap, 2018). Strategies for effective participation can include specialised court staff and child-friendly language (FRA, 2015). It has been said that 'authentic inclusion of children's participation requires much more than a comfortable waiting room or a stuffed animal gift' (Berrick et al., 2018). In bridging the theory to practice gap, a recent collection (Stalford, Hollingsworth and Gilmore, 2017) has extended the re-writing of judgments methodology pioneered by feminist legal scholars to re-write a selection of judgments from a children's rights perspective.

\subsubsection{Children Deprived of Liberty}

Children deprived of liberty has been an issue of concern for a long time. The Global Study on Children Deprived of Liberty, commissioned by the United Nations, has aimed to provide a better understanding of the phenomenon, in the context of criminal justice and beyond. It has targeted at identifying promising practices with regard to the prevention of arrest, detention or imprisonment, the promotion of diversion and non-custodial measures, and the protection of children deprived of liberty (UN Global Study, 2019; see also the full report published in November 2019). Key facts reported in this study include 160,000-250,000 children in remand centres and prisons worldwide, overuse of pre-trial detention, reliance on repressive and punitive policies leading to excessive criminalisation, overrepresentation of certain groups of children, serious concerns about children's rights and well-being.

Indeed, there are grave concerns about the widespread use of deprivation of liberty in the criminal justice and other systems, and there are numerous report pointing at the absence of adequate prevention strategies, the lack of protection of children's rights and freedoms, including a lack of protection against various forms of violence, and the negative impact of deprivation of liberty on children's health, development, safety and reintegration (see e.g. Mendez, 2015). It needs no explanation that these concerns relate to the very core of children's rights and interests.

Yet, it remains important to highlight that the vast majority of interventions used in criminal justice systems across the globe have a non-custodial nature. In addition, the numbers of children deprived of liberty have fallen around the world, particularly in the past ten years. Even in countries that have a rather bad record in terms of the numbers of children being placed in detention or being imprisoned in whatever form, such as the United States of America and England, now show a steady decrease of the number of incarcerated children (see e.g. Bateman, 2012; ACLU, 2019). This can certainly be regarded as a positive development although it also has implications for the complexity of the group of children that find themselves in detention (Hollingsworth, 2014; see 
further below). Moreover, there remain significant concerns about disparities and inequalities in the context of detention, as well as the use of severe sentences regarding children (see also below).

\section{3}

Gaps and Challenges for Children's Rights

In this section we set out three challenges for the coming decades. Without disregarding that in many national systems there still are basic concerns with regard to children's rights implementation (such as lack of adequate legislation, high reliance on detention and lack of resources), what are some of the difficult and complex issues which scholars and advocates for children must address?

\subsection{From Critique to Reform - A Children's Rights Compliant Approach to Serious Offending}

Our knowledge of children's offending patterns is that most offending committed by children falls into the minor to moderate range. Children's offending is characterised mainly by property offences, anti-social behaviour, less serious assaults, status offences and traffic offences. A children's rights compliant approach to such cases is one which is diversionary, tolerant and timely, and which addresses the criminogenic and welfare issues which have contributed to the offending (Article 40.1, Convention). The human rights framework for children provides considerable guidance on prevention of offending, early intervention and diversionary processes, emphasising the importance of reintegration.

Nonetheless, there is considerably less guidance on the principles, process and outcomes for children who commit very serious offences. By this term, we mean offences such as homicide, rape, terrorism and aggravated robbery and assault. These offences involve a high degree of harm and wrong. Even otherwise progressive jurisdictions use an exclusionary approach, particularly for children accused or convicted of homicide. This may mean that all or part of the trial is held in the adult system, and that adult sentences such as life imprisonment are available and are imposed (Lynch, 2018). The effect of an adult trial on children is harsh, even where protective measures such as intermediaries and special procedures are used. Opportunities for effective and meaningful participation are likely to be limited, and timeframes between charge and resolution are not likely to be in line with a child's sense of time. The use of indeterminate or lengthy sentences of imprisonment solely for retributive purposes contravenes the requirements in the Convention to use detention as a last resort and where public safety is at risk. 
Scholarship in this area has rightly identified how punitive sentences contravene children's rights (O'Brien and Fitz-Gibbon, 2016). Capital punishment (Linde, 2011; James and Cecil, 2003-4). However, there is less discussion of what a children's rights approach to such cases involve. Grappling with a principled approach to this issue involves consideration of what the public interest is in cases of offending by children and what weight should be placed on public safety (Kay, Tisdall and Docherty, 1998; Covell and Howe, 1996). Further, the rights and interests of victims of crime within the framework of children's rights standards requires further examination. This is particularly relevant where the victim or alleged victim of the offence is also a child. The interests and rights of both children, including their best interests, must be considered in these cases (Lynch, 2018).

As well as the conceptual issues to be considered and weighed, the operational and policy questions of what a children's rights compliant approach looks like for serious cases must be addressed by scholars and advocates. If children's rights scholars cannot say what a children's rights compliant response looks like - how can we advocate at a policy and government level for change? The punitive status quo is likely to persist unless viable alternatives which acknowledge the public's legitimate interest in accountability for serious offending are proposed.

\section{2 \\ Addressing Over-Representation and Disparity of Outcomes for Minority Groups}

As foreshadowed above, the most pressing and difficult challenge for children's rights in the coming decades is the over-representation of certain groups of children in the criminal justice system. This is accompanied by disparity of outcomes of treatment.

Though the minority groups differ, the trends are depressingly similar in relation to ethnic and racial minorities:

- The Lammy Report (2017) in the United Kingdom reports that BAME children make up 41 per cent of those in custody, and that young black men are nine times more likely to be in custody than white young men;

- New Zealand's latest court figures indicate that in 2018, Mãori made up 63 per cent of children and young people with charges finalised in court (Ministry of Justice, 2018);

- In the Netherlands, research suggests that children with a migrant background (among others, children with a Moroccan background) have a higher chance of remaining in pre-trial detention, while children with a nonmigrant background have a higher chance that their pre-trial detention will be suspended (Van den Brink et al., 2017); 
- In the United States, black children are highly over-represented at all stages of the justice system (Ghandnoosh, 2014).

Female children too face particular issues, with their offending seen to transgress societal views on norms of femininity as well as the criminal law (Lynch, 2014). The small numbers of female children in the criminal justice system also means that such children are often left worse off as specific and separate reintegrative and rehabilitative programmes are not available (Lynch, Fortune, Ward et al., 2018). There are also growing concerns with regard to children with (mental) disabilities and the way they are being treated within the justice system (Van den Brink et al., 2017). The causes of over-representation and disparity of outcomes are incredibly complex and cannot be disentangled from historical and contemporary societal factors such as colonialism, discrimination and poverty of opportunity (De Jonge, 1995; Douglas and Walsh, 2013).

Further, the increasing prevalence and lightly regulated development of the use of new technology for state surveillance, criminal justice processing and risk assessment is also concerning, and will require child-specific analysis of impact, particularly for minority children. For instance, the collection and retention of DNA has been recognised as having particular impacts on children's bodily integrity, privacy and reintegration, and being particularly stigmatising on racial and ethnic minorities (Campbell and Lynch, 2012). In New Zealand, a recent issues paper released by the Law Commission reports that 67 per cent of the profiles of children and youth held on the databank are of Māori descent, entrenching the bias and over-representation in the system (Law Commission, 2019). Emerging state surveillance tools such as automatic facial recognition technology must be assessed for their impact on children. Digital worlds mean new sources of potential harm to children (Simpson) Children's rights in a digital age of rapidly emerging technology is already a developing area of scholarship (Lievens et al., 2018; Livingstone and O'Neill, 2014).

\subsection{Shifting Concepts of Childhood, Youth and Emerging Adulthood}

Much literature on children in conflict with the law is concerned with the age parameters of the system. As we discuss above, there is no firm minimum age of criminal responsibility nor an age of penal majority mentioned in the Convention, though children are defined as being those less than 18 (at the time of committing the offence). While many jurisdictions still need to ensure that all children aged less than 18 have the benefit of a specialised protective youth justice system, there has been a cross-national trend towards enactment or consideration of the extension of the youth justice system to include young adults (Dünkel and Pruin, 2012). 
There are a number of drivers for this trend, including the extension of the social concept of adolescence. While in former times indicators of adulthood such as marriage, childbearing and entry into the workforce was likely to occur at much earlier ages, it is now accepted that young adults are often not independent until their early to mid-twenties. Further, increased understanding of brain development in late adolescence has influenced policy. Also within the context of human rights, which builds on the notion that childhood ends at the age of 18, there seems to be a growing awareness around the importance of addressing the position of young adults. This has resulted in some specific guidance towards states on how to deal with children in transition from the juvenile into the criminal justice system (Liefaard, 2012). A positive aspect of increasing understanding of brain development is that young or emerging adults' (a term used for those roughly between the ages of 18 and 25) vulnerabilities and lesser capacities are being recognised through law, policy and practice (Brewster, 2019). The vulnerability, lesser capacity and culpability of this group recognised through approaches like increasing the jurisdiction of the youth justice system or establishing a third system.

There are some challenges in these shifting concepts of childhood, youth and emerging adulthood. The development of these policies for lower-risk emerging adults coupled with the exclusion from protective measures of some children for serious offending may mean a categorisation of deserving/ undeserving or risky/not risky. This is compared to the "bright-line" test in children's rights standards of protective measures being predicated on the child's age rather than their level of risk or seriousness of the offence. It is also worth considering whether there are any challenges for the wider field of children's rights. In particular, is there a cognitive dissonance in children's rights scholarship, where in other fields such as education, medical decision-making, voice of the child, citizenship and gender identity, we consider and advocate that even young children are capable of exercising agency and autonomy and to appreciate the consequences of their proposed decisions (Hollingsworth, 2007). Is this a consistent approach? Or is there a need for consistency? (Yaffe, 2018).

We have posed a number of challenges for scholars and advocates who are working in the area of the rights of children in conflict with the law. These are three examples from our perspective, but this list is not exhaustive. To conclude, we briefly consider how we think the children's rights community should tackle these issues. To continue on a theme - we suggest three ways 
that scholarship and advocacy can address these challenges, and the fresh challenges to come.

First, the value of comparative research and engagement. There is much to be learned from other jurisdictions, particularly between common law and civil law jurisdictions. There is also much to be learnt by Western scholars from engaging (appropriately and respectfully) with concepts and models from indigenous and other cultures (Libesman, 2007; Kaime, 2010), and with informal justice systems apparent in different parts of the world (see e.g. ACPF, 2018). It is very useful to consider comparative aspects such as court orders available, but analysis needs to consider what the actual impact is on children, e.g. there may be different reasons for detention (retributive or child welfare or protective), but the effect on the child is the same in terms of deprivation of liberty.

Secondly, the value of interdisciplinary scholarship and engagement must be emphasised. As we better recognise the complexities of our population of children in conflict with the law, upholding their rights and ensuring childfriendly justice will involve considering and applying knowledge from a range of scholarly disciplines, including medicine, public health, big data and economics. In relation to this, we need to be aware of the ethical issues related to and political implications of our work, as well as of the potential implications of scientific insights for the consistency of our approaches to children and adolescents (see the challenge related to shifting concepts of childhood and youth).

Thirdly, moving beyond critique into co-design is vital. It is relatively easy for scholars and advocates to critique law, policy and practice as being noncompliant with children's rights standards, but more difficult to work in balancing the various rights and interests inherent in law reform and policy formation. Scholars and advocates for children must ensure that they are involved and engaged in policy and law reform, which should also include critical and independent evaluation (see also General Comment No. 24, para. 114, where the Committee recommends that States parties ensure regular evaluations of their child justice systems, in particular of the effectiveness of the measures taken, and in relation to matters such as discrimination, reintegration and patterns of offending, preferably carried out by independent academic institutions.).

\section{References}

ACLU, 2019, American's Addiction to Juvenile Incarceration: State by State: https:// www.aclu.org/issues/juvenile-justice/youth-incarceration/americas-addictionjuvenile-incarceration-state-state (last visited 13 June 2019). 
ACPF, 2018, Spotlighting the Invisible: Justice for children in Africa: http://www .africanchildforum.org/en/index.php/en/resource-centre.html?pid=2\&sid= 201:spotlighting-the-invisible-justice-for-children-in-africa (last visited 26 October 2019).

Ame, Robert Kwame, "The Rights of Children in Conflict with the Law in Ghana" (2011) 19 The International Journal of Children's Rights 271.

Banks, Cyndi, "Protecting the Rights of the Child: Regulating Restorative Justice and Indigenous Practices in Southern Sudan and East Timor" (2011) 19 The International Journal of Children's Rights 167.

Banks, Cyndi, “The Discourse of Children's Rights in Bangladesh: International Norms and Local Definitions" (2007) 15 The International Journal of Children's Rights 391.

Bateman, T. (2012), "Who Pulled the Plug? Towards an Explanation of the Fall in Child Imprisonment in England and Wales", Youth Justice, 12/1: 36-52.

Berrick, J. D., Dickens, J., Pösö, T. and Skivenes, M. (2018), “International perspectives on child-responsive courts", The International Journal of Children's Rights, 26(2): 251-277.

Borowski, A. (2011), "In Courtroom 7 -The Children's Koori Court at Work: Findings From an Evaluation", International journal of offender therapy and comparative criminology, 55(7): 1110-1134.

Brewster, D. (2019), "Not Wired Up? The Neuroscientific Turn in Youth to Adult (Y2A) Transitions Policy", Youth Justice, 1473225419876458.

Campbell, L. and Lynch, N. (2012), "Competing paradigms? The use of DNA powers in youth justice", Youth Justice, 12(1): 3-18.

Cipriani, Don, Children's rights and the minimum age of criminal responsibility: a global perspective, Routledge, 2016.

Cohen, A. O. and Casey, B. J. (2014), "Rewiring juvenile justice: The intersection of developmental neuroscience and legal policy", Trends in cognitive sciences, 18(2): $63-65$.

Covell, Katherine R., Brian Howe, "Public Attitudes and Juvenile Justice in Canada" (1996) 4 The International Journal of Children's Rights 345 .

Crawford, A. and Newburn, T. (2013), Youth offending and restorative justice, Willan.

Cunneen, C. (2006), "Racism, discrimination and the over-representation of Indigenous people in the criminal justice system: Some conceptual and explanatory issues", Current issues in criminal justice, 17(3):329-346.

Daly, A. and Rap, S. (2018), "Children's Participation in Youth Justice and Civil Court Proceedings", International Human Rights of Children: 1-21.

De Jonge, A., "Australia's Aboriginal Youth and the UN Convention on the Rights of the Child" (1995) 3 The International Journal of Children's Rights 69.

Delmage, E. (2013), "The minimum age of criminal responsibility: A medico-legal perspective", Youth justice, 13(2): 102-110. 
Douglas, Heather and Tamara Walsh (2013), "Continuing The Stolen Generations: Child Protection Interventions And Indigenous People”, The Intemational Joumal of Children's Rights, 2: 59-87.

Dünkel, F. and Pruin, I. (2012), "Young adult offenders in juvenile and criminal justice systems in Europe", Young adult offenders: lost in transition: 11-38.

Eekelaar, J. (1991), "Parental responsibility: State of nature or nature of the state?", The Journal of Social Welfare \& Family Law, 13(1), 37-50.

Feria-Tinta, M. (2015), "The CRC as a litigation tool before the Inter-American System of Protection of Human Rights" in T. Liefaard and J. E. Doek (eds.), Litigating the Rights of the Child. The UN Convention on the Rights of the Child in Domestic and International Jurisprudence. Dordrecht: Springer: 231-248.

Fitz-Gibbon, K. (2016), "Protections for children before the law: An empirical analysis of the age of criminal responsibility, the abolition of doli incapax and the merits of a developmental immaturity defence in England and Wales", Criminology \& Criminal Justice, 16(4): 391-409.

Forde, L. (2018), "Realising the Right of the Child to Participate in the Criminal Process", Youth Justice, $18(3): 265^{-284}$.

FRA: European Union Agency for Fundamental Rights, Child friendly justice: Perspectives and experiences of professionals on children's participation in civil and criminal judicial proceedings in 10 EU member states (Luxembourg: Publication office of the European Union 2015).

Freckelton, I. (2016), "Sentencing Offenders with Foetal Alcohol Spectrum Disorder (FASD): The Challenge of Effective Management: Churnside v The State of Western Australia [2016] WASCA 146 per Martin CJ and Mazza and Mitchell JJA", Psychiatry, Psychology and Law, 23(6): 815-825.

Ghandnoosh, N. (2014), "Black Lives Matter: Eliminating Racial Inequity in the Criminal Justice System", Washington, D.C.: The Sentencing Project.

Grisso, T. E. and Schwartz, R. G. (2000), Youth on trial: A developmental perspective on juvenile justice, University of Chicago Press.

Hand, L., Pickering, M., Kedge, S. and McCann, C. (2016), "Oral language and communication factors to consider when supporting people with FASD involved with the legal system" in Fetal alcohol spectrum disorders in adults: Ethical and legal perspectives (139-147), Springer, Cham.

Hollingsworth, K. (2007), "Responsibility and rights: Children and their parents in the youth justice system", International Journal of Law, Policy and the Family, 21(2): 190-219.

Hollingsworth, Kathryn, "Assuming Responsibility for Incarcerated Children: A Rights Case for Care-based Homes" 67(1) Current Legal Problems 67, no. 1 (2014): 99-134.

Hollingsworth, Kathryn, "The Utility and Futility of International Rights Standards for Children in Conflict with the Law: The Case of England" in Routledge International 
Handbook of Criminology and Human Rights, Leanne Weber, Elaine Fishwick, Marinella Marmo (eds.) (Abingdon: Routledge, 2016).

Hollingsworth, Kathryn, “Theorising Children's Rights in Youth Justice: the Significance of Autonomy and Foundational Rights", Modern Law Review 76, no. 6 (2013): 1046-69.

Hoyano, L. (2015), "Reforming the adversarial trial for vulnerable witnesses and defendants", Criminal Law Review, 2:107-129.

Hughes, N., Williams, H., Chitsabesan, P., Davies, R., \& Mounce, L. (2012), "Nobody made the connection: The prevalence of neurodisability in young people who offend", London, UK: The Office of the Children's Commissioner.

James, Anne and Joanne Cecil, "Out of Step: Juvenile Death Penalty in the United States" (2003-2004) 11 The International Journal of Children's Rights 291.

Kaime, Thoko (2010), "Vernacularising' The Convention On The Rights Of The Child: Rights And Culture As Analytic Tools", The International Journal of Children's Rights, 18: $637-653$.

Kay, E; M.Tisdall, J. Brown and M. Docherty, “Children's Best Interests versus Public Safety: How Are They Balanced" (1998) 6 The International Journal of Children's Rights 395.

Kempf-Leonard, K. (2007), "Minority youths and juvenile justice: Disproportionate minority contact after nearly 20 years of reform efforts", Youth Violence and Juvenile Justice, $5(1)$ : 71-87.

Kilkelly U., Liefaard T. (2019a), "International Children's Rights: Reflections on a Complex, Dynamic, and Relatively Young Area of Law" in Kilkelly U., Liefaard T. (eds.), International Human Rights of Children. International Human Rights, Springer, Singapore.

Kilkelly, U. (2001), “The Best of Both Worlds for Children's Rights-Interpreting the European Convention on Human Rights in the Light of the UN Convention on the Rights of the Child", Human Rights. Quarterly, 23: 308.

Kilkelly, U. (2008), "Youth Courts and Children's Rights: The Irish Experience”, Youth Justice, 8(1): 39-56.

Killkelly, U. and Liefaard, T (eds.), International Human Rights of Children, Springer, 2019.

Lammy, D. (2017), The Lammy review: An independent review into the treatment of, and outcomes for, Black, Asian and Minority Ethnic individuals in the Criminal Justice System, HM Government.

Libesman, Terri (2007), "Can International Law Imagine The World Of Indigenous Children?", The International Journal of Children's Rights, 15: 283-309.

Liddell, M., Blake, M. and Singh, S. (2017), "Over-represented and misunderstood: Pacific young people and juvenile justice in Nsw", Australian \& New Zealand Journal of Criminology, 5o(4): 529-547. 
Liefaard T. and Kilkelly U. (2018), "Child-friendly justice: past, present and future" in B. Goldson (ed.), Juvenile justice in Europe: Past, present and future, New York/ London: Routledge.

Liefaard T. and Van den Brink, Y. N. (2014), “Juveniles' Right to Counsel during Police Interrogations: An Interdisciplinary Analysis of a Youth-Specific Approach, with a Particular Focus on the Netherlands", Erasmus Law Review 7(4): 206-218.

Liefaard T. (2012), "Juveniles in transition from juvenile justice to adult criminal justice" in Loeber et al. (eds.), Persisters and Desisters in Crime from Adolescence into Adulthood: Explanation, Prevention, and Punishment (159-200), Ashgate, Aldershot.

Liefaard, T. (forthcoming), "Juvenile Justice", in Todres J. and King Sh. (eds.), The Oxford Handbook of Children's Rights Law, New York: Oxford University Press.

Liefaard, T. (2018), "Deprivation of Liberty of Children" in U. Kilkelly and T. Liefaard (eds.), The International Human Rights of Children, Singapore: Springer.

Liefaard, T. (2015), "Juvenile justice from an international children's rights perspective", Routledge International Handbook of Children's Rights Studies: 234.

Lievens, E., Livingstone, S., McLaughlin, S., O'Neill, B. and Verdoodt, V. (2018), "Children's rights and digital technologies", International human rights of children, 1-27.

Linde, Robyn, "From Rapists to Superpredators: What the Practice of Capital Punishment Says about Race, Rights and the American Child" (2011), 19 The International Journal of Children's Rights 127.

Livingstone, S. and O’Neill, B. (2014), “Children's rights online: Challenges, dilemmas and emerging directions" in Minding minors wandering the web: Regulating online child safety (19-38), TMC Asser Press, The Hague.

Lynch, N. (2016), "Neurodisability in the youth justice system in New Zealand: How vulnerability intersects with justice", Dyslexia Foundation, Wellington.

Lynch, N. (2018a), "Towards a Principled Legal Response to Children Who Kill”, Youth Justice, vol 18 no. 3: 211-229.

Lynch, N. (2018b), “Human Rights for 'Hard Cases': Alternatives to Imprisonment for Serious Offending by Children and Youth" in Human Rights and Incarceration (153179), Palgrave Macmillan, Cham.

Lynch, N. (2018c), “'The Other Child'-The Rights of the Child Victim in the Youth Justice System", The International Journal of Children's Rights, vol. 26 no. 2: 228-250.

Maxwell, G. and Morris, A. (2006), "Youth justice in New Zealand: Restorative justice in practice?", Journal of Social Issues, 62(2) : 239-258.

McDiarmid, C. (2013), "An age of complexity: Children and criminal responsibility in law", Youth justice, 13(2): 145-160.

Millerv. Alabama, 567 U.S. 460 (2012).

Monahan, Kathryn Laurence Steinberg and Alex R. Piquero, "Juvenile Justice Policy and Practice: A Developmental Perspective", Crime and Justice 44 (2015): 577-619. 
Moore, S. A., Rights-Based Restorative Practice: Evaluation Toolkit (2008). Available at: http://www1.umn.edu/humanrts/links/RBRJ\%2otoolkit.pdf (last viewed 1 October 2019).

Morgan, R. and Farmer, E. (2011), "The age of criminal responsibility: developmental science and human rights perspectives", Journal of children's services.

Morris, A. and Maxwell, G. (eds.) (2001), Restorative justice for juveniles: Conferencing, mediation and circles, Bloomsbury Publishing.

Nunez, Llifen Palacios and Anna Copeland, "Solitary Confinement within Juvenile Detention Centres in Western Australia" (2017) 25 The International Journal of Children's Rights 716.

O'Brien, Wendy and Kate Fitz-Gibbon, “Cemented in their cells': a human rights analysis of Blessington, Elliott and the life imprisonment of children in New South Wales", Australian Journal of Human Rights 22, no. 1 (2016): 111-133.

O’Brien, Wendy and Kate Fitz-Gibbon, “Can Human Rights Standards Counter Australia's Punitive Youth Justice Practices” (2018) 26 The International Journal of Children's Rights 197.

Rap S. E. and Zlotnik D. (2018), "The right to legal and other appropriate assistance for child suspects and accused. Reflections on the EU Directive on procedural safeguards for children who are suspects or accused persons in criminal proceedings", European Journal of Crime, Criminal Law and Criminal Justice, 26, 110-131.

Rap S. E. (2016), "A Children's Rights Perspective on the Participation of Juvenile Defendants in the Youth Court", The International Journal of Children's Rights, 24/1: 93-112.

Rap, S. (2015), "The implementation of the right to be heard in juvenile justice proceedings in Europe", The EU as a Children's Rights Actor: Law, Policy and Structural Dimensions: 133 .

Richards, Kelly, Lorana Bartels and Jane Bolitho, "Children's court magistrates' views of restorative justice and therapeutic jurisprudence measures for young offenders", Youth Justice 17, no. 1(2017), 22-40.

Richards, Kelly, Bartels Lorana and Bolitho Jane, "Children's court magistrates' views of restorative justice and therapeutic jurisprudence measures for young offenders", Youth Justice 17, no. 1(2017), 22-40.

Rutkow, L. and Lozman, J. T. (2006), Suffer the Children: A Call for United States Ratification of the United Nations Convention on the Rights of the Child, Harvard Human Rights Journal, 19, 161.

Sands, C. (2016), "Growing up, Moving on", The International Treatment of Childhood Criminal Records. Report, London: Standing Committee for Youth Justice.

Scott, E. S. and Steinberg, L. (2008), "Adolescent development and the regulation of youth crime", The Future of Children: $15^{-33}$. 
Simpson, B. (2013), "Challenging childhood, challenging children: Children's rights and sexting”, Sexualities, $16\left(5^{-6}\right)$, 690-709.

Skelton, A. (2018), "Child Justice in South Africa: Application of International Instruments in the Constitutional Court", The International Journal of Children's Rights, $26 / 3$.

Sloth-Nielsen, J. (2001), The Influence of International Law on South Africa's Juvenile Justice Reform Process, LLD thesis, University of the Western Cape.

Sloth-Nielsen, J. (2015), "What's in a Name? "Child-friendly" Justice in Africa" in Mahmoodi, S. (ed.), Child Friendly Justice. Stockholm Studies in Child Law and Children's Rights No. 1, Brill publishers, 315-333.

Sparks, Richard, Evi Girling and Marion Smith, "Children Talking about Justice and Punishment” (2000), 8 The International Journal of Children's Rights 191.

Stalford, H., Hollingsworth, K. and Gilmore, S. (eds.). (2017), Rewriting children's rights judgments: From academic vision to new practice, Bloomsbury Publishing.

Stanley, E. (2017), "From care to custody: trajectories of children in post-war New Zealand", Youth justice, 17(1): 57-72.

Steinberg, L. and Scott, E. S. (2003), "Less guilty by reason of adolescence: developmental immaturity, diminished responsibility, and the juvenile death penalty", American Psychologist, 58 (12): 1009.

Steinberg, L. (2009), "Should the science of adolescent brain development inform public policy?", American Psychologist, 64(8): 739 .

Taumaunu, H. (2014), "Rangatahi Courts of Aotearoa/New Zealand - An Update", Māori Law Review, 22(11): 1.

UN Committee on the Rights of the Child, Draft General Comment No. 24 replacing General Comment No. 10 on Children's rights in juvenile justice: https://www.ohchr .org/Documents/HRBodies/CRC/GC24/GeneralComment24.pdf (last visited 13 June 2019).

UN Committee on the Rights of the Child, General Comment No. 10: Children's rights in juvenile justice, UN Doc. CRC/C/GC/10, 25 April 2007 (General Comment No. 10).

UN Human Rights Council. 2015, Report of the Special Rapporteur on torture and other cruel, inhuman or degrading treatment or punishment, UN Doc. A/HRC/28/68 (Mendez, 2015).

Van den Brink, Y. (2018), Voorlopige hechtenis in het Nederlandse jeugdstrafrecht: wet en praktijk in het licht van internationale en Europese kinder - en mensenrechten, Dissertation, Leiden University. Deventer: Wolters Kluwer.

Van den Brink, Y., Hermink, H. T., Bolscher, K. G. A., Van Leeuwen, C. M. M., Bruning, M. R. and Liefaard, T. (2017), Voorlopige hechtenis van jeugdigen in uitvoering. Een exploratief kwantitatief onderzoek naar rechterlijke beslissingen en populatiekenmerken, Wolf Legal Publishers. 
Walsh, C. (2010), "Youth justice and neuroscience: A dual-use dilemma", The British Journal of Criminology, 51(1), 21-39.

Webster, C. (2018), "Race', ethnicity, social class and juvenile justice in Europe", in Juvenile Justice in Europe (168-181), Routledge.

Welfare and Family Law $5,37$.

Yaffe, G. (2018), The Age of Culpability: Children and the Nature of Criminal Responsibility, Oxford University Press.

Zimring, F. E., Langer M. and Tanenhaus, D.S. (eds.) (2015), Juvenile Justice in Global Perspective, New York/London: New York University Press. 